\title{
Silicon Potential as Attenuator of Salinity Effects on Growth and Post-harvest Quality of Lettuce
}

\author{
Hozano de Souza Lemos Neto ${ }^{1}$, Marcelo de Almeida Guimarães ${ }^{1}$, Rosilene Oliveira Mesquita ${ }^{1}$, \\ Italo Marlone Gomes Sampaio ${ }^{2}$, Ana Régia Alves de Araújo Hendges ${ }^{3} \&$ Alexandre Bosco de Oliveira $^{1}$ \\ ${ }^{1}$ Department of Fitotecnia, Federal University of Ceará, Fortaleza, Ceará, Brazil \\ ${ }^{2}$ Federal Rural University of Amazonia, Institute of Agrarian Sciences, Department of Soils, Belém, Pará, Brazil \\ ${ }^{3}$ Federal Institute of Education, Science and Technology of Maranhão, São Raimundo das Mangabeiras, \\ Maranhão, Brazil
}

Correspondence: Hozano de Souza Lemos Neto, Department of Fitotecnia, Federal University of Ceará, Fortaleza, Ceará, Brazil. E-mail: hozanoneto@hotmail.com

Received: April 6, 2018

doi:10.5539/jas.v10n7p455
Accepted: May 8, 2018 Online Published: June 15, 2018

URL: https://doi.org/10.5539/jas.v10n7p455

\begin{abstract}
Silicon $(\mathrm{Si})$ is a mineral element that provides many benefits to plants and may also assist in tolerance to abiotic stresses such as salinity. The aim of the study was to evaluate the use of $\mathrm{Si}$ as a possible attenuator of the deleterious effects of salinity on growth and post-harvest of lettuce. A completely randomized design with four replicates was performed in a $3 \times 2$ factorial, consisting of three salinity levels $\left(1.65,3.65,7.65 \mathrm{dS} \mathrm{m}^{-1}\right)$ and two levels of silicon $(0.0$ and $2.0 \mathrm{mM})$. Salinity reduced all variables related to plant growth. For shoot fresh and dry mass, it was observed that $\mathrm{NaCl}$ caused a reduction of 79.80 and $80 \%$, respectively, in comparison to the control. However, parameters related to post-harvest such as titratable acidity, soluble solids and vitamin $\mathrm{C}$ increased with salinity. Although not effective in reducing saline stress on plant growth, Si provided improvements in the variables related to lettuce post-harvest. Salinity significantly reduced plant growth in the presence and absence of $\mathrm{Si}$, but provided better post-harvest quality with $\mathrm{Si}$.
\end{abstract}

Keywords: Lactuca sativa L., salt stress, silicate fertilization, $\mathrm{NaCl}$, vitamin $\mathrm{C}$

\section{Introduction}

Salinity is one of the abiotic stresses that most limits crop production (Munns \& Tester, 2008). Currently, it is estimated that about $20 \%$ of the cultivated soils and about $33 \%$ of the irrigated areas in the world face some problem of salinization (Shahbaz \& Ashraf, 2013; Shrivastava \& Kumar, 2015). Except Antarctica, all other continents present soils with salinity problems (Martinez-Beltran \& Manzur, 2005).

These problems become even more evident in arid and semi-arid regions. In these environments, due to the high evaporation and low precipitation and with the low leaching capacity of the soils, salts accumulate on the surface in amounts that are harmful to the plants. In addition, water scarcity forces the use of saline waters from deep wells in irrigation. These wells, in general, have high salt contents ranging from 0.1 to $5.0 \mathrm{dS} \mathrm{m}^{-1}$ (Costa et al., 2004). Therefore, it is necessary to look for alternatives to produce under these conditions. In this sense, silicate fertilization can be an important alternative to reduce saline stress and improve post-harvest quality of fruits and vegetables.

Fertilization supplemented with silicon, has shown positive responses related to the gain in production and post-harvest quality of some vegetables such as lettuce (Resende et al, 2007; Galati et al, 2015b), strawberry (Figueiredo, 2010) tomato (Marodin et al., 2016). In conditions of salt stress, positive effects of this mineral have already been verified in crops such as wheat, cashew, rice, corn, tomato, among others (Tuna et al., 2008; Miranda et al., 2010; Kraska \& Breitenbeck, 2010; Lima et al., 2011; Li et al., 2015).

Lettuce (Lactuca sativa L.) is a leafy vegetable considered as "moderately sensitive" to the effects of salinity, and its production declines by approximately $13 \%$ by each unit of increase in salinity threshold, which is $1.3 \mathrm{dS}$ $\mathrm{m}^{-1}$ (Maas, 1986). For being the most consumed leafy vegetable in the world and present in the diet of the Brazilian population, with an annual domestic production of around 1.7 million tonnes (ABCSEM, 2014), studies with this hardwood are necessary to soften the effects of salinity in areas suffering from this problem. 
Studies with the use of $\mathrm{Si}$ in vegetables, such as lettuce, aiming at attenuating the negative effects of salinity, are still incipient and not very informative. Thus, the aim of this study was to evaluate the potential of silicon in reducing the effects of salinity on lettuce growth and post-harvest.

\section{Material and Methods}

\subsection{Experimental Area}

Experiment was carried out from October to November 2016, in protected environment conditions, in Fortaleza-CE at $3^{\circ} 44^{\prime} \mathrm{S}, 38^{\circ} 33^{\prime} \mathrm{W}$ and average altitude of $14 \mathrm{~m}$. The climate is type 'As', that is, tropical with dry season (Alvares et al., 2013). The average annual rainfall is $1.448 \mathrm{~mm}$, relative humidity of $78.8 \%$, with a minimum and maximum average temperature of $23.6{ }^{\circ} \mathrm{C}$ and $30.1{ }^{\circ} \mathrm{C}$, respectively.

The protected environment used in this research was a screened nursery with a $30 \%$ shading material, ceiling height of approximately $1.8 \mathrm{~m}$, with length and width of approximately $8.0 \mathrm{~m}$ each. Maximum and minimum air temperature and relative humidity values recorded in the nursery were $36.4{ }^{\circ} \mathrm{C}, 25.4{ }^{\circ} \mathrm{C}$ and $78.3 \%, 25 \%$, respectively, and average luminous intensity of 89.775 Lux.

\subsection{Sowing and Cultivation Conditions}

Seeds of 'Lucy Brown' were seeded in phenolic foam, with dimensions of $2 \times 2 \times 2 \mathrm{~cm}$. One seedling per cell was maintained, and received two irrigations daily during ten days. After this period, seedlings were transferred to polyethylene trays containing $7 \mathrm{~L}$ of nutrient solution at $50 \%$ of ionic strength, for adaptation during seven days (nursery phase). Subsequently, they were transplanted to hydroponic system with $5 \mathrm{~L}$ pots with nutrient solution of Furlani et al. (1999) at $100 \%$ of ionic strength, where they were submitted to the different levels of silicon $(0.0$ and $2.0 \mathrm{mM})$ and salinity, 1.65 (control); $3.65 ; 7 \mathrm{dS} . \mathrm{m}^{-1}$. Sodium silicate $\left(\mathrm{Na}_{2} \mathrm{SiO}_{3}\right)$ was used as silicon source and sodium chloride $(\mathrm{NaCl})$ was used for induction of saline stress.

Water used in the preparation of nutrient solution was C2S1 (Table 1), obtained from the supply of Companhia de Água e Esgoto do Ceará (Cagece), whose values of electrical conductivity were adjusted with a conductivity meter with temperature correction.

Table 1. Chemical characteristics of water used in the preparation of the nutritive solution

\begin{tabular}{|c|c|c|c|c|c|c|c|}
\hline $\mathrm{pH}$ & $\mathrm{CE}$ & $\mathrm{Ca}^{2+}$ & $\mathrm{Mg}^{2+}$ & $\mathrm{K}^{+}$ & $\mathrm{Na}^{+}$ & $\mathrm{Cl}^{-}$ & $\mathrm{HCO}_{3}^{-}$ \\
\hline & -- $\mathrm{dS} \mathrm{m}^{-1}$-- & $-\cdots$ & & 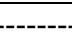 & $\mathrm{c}^{-1}-$ & - -- & \\
\hline 7.0 & 0.46 & 0.40 & 2.30 & 0.80 & 1.10 & 3.20 & 1.40 \\
\hline
\end{tabular}

Source: Soil and water laboratory of UFC.

The hydroponic system type used was "floating" (deep pool with static aeration system), installed on a wooden counter ( $0.8 \mathrm{~m}$ high, $1.5 \mathrm{~m}$ wide and $3.0 \mathrm{~m}$ long). For the aeration of nutrient solution, air compressors Chang $9000,220 \mathrm{v}$ were used. Due to evapotranspiration, daily water replacement was performed in all pots for the initial volume $(5 \mathrm{~L})$, as well as $\mathrm{pH}$ adjustment of the nutrient solution with citric acid $\left(\mathrm{C}_{6} \mathrm{H}_{8} \mathrm{O}_{7}\right)$ or sodium hydroxide $(\mathrm{NaOH})$ keeping it in a range of 5.5 to 6.5. Every five days, renewal of nutrient solution was performed. Fourty days after sowing, plants were harvested and taken to the laboratory for growth and post-harvest analyses.

\subsection{Analysis of Plant Growth}

Plants were harvested and separated into roots and shoot. Then, root and shoot length (RL and SL) were determined with the aid of a graduated ruler $(\mathrm{cm})$; root and shoot fresh mass (RFM and SFM) were measured weighing roots and shoot parts (leaves + stems) in precision scale with four decimal places. Then, leaf area (LA) was determined through a leaf area meter (LI-COR, Inc. Model LI-3000) with the results expressed in $\mathrm{cm}^{2}$ and the number of leaves (NL) by counting the fully expanded leaves. Afterwards, the different parts of the plant were dried in a forced air oven at $65^{\circ} \mathrm{C}$ until reaching constant mass, and then weighed to obtain root and shoot dry mass (RDM and SDM), expressed in g.planta ${ }^{-1}$. Production reduction (PR) was also calculated by the following formula:

$$
(P R, \%)=[(\mathrm{PCT}-\mathrm{PST}) /(\mathrm{PCT})] \times 100
$$

where, $\mathrm{PCT}=$ production of the control treatment (without salinity); PST $=$ production of the salinity treatment (Fageria, 1985, 1992). SDM was considered as production parameter. 


\subsection{Post-harvest Quality Analysis of Leaves}

Part of the plant material was taken to the laboratory, where they were macerated and then used to determine the parameters described below:

(1) Titratable acidity (TA): determined in $1 \mathrm{~g}$ of macerated leaf, transferred to a $125 \mathrm{ml}$ Erlenmeyer flask and filling the volume to $50 \mathrm{ml}$ with distilled water. Phenolphthalein indicator $1 \%$ was used and titration with $0.1 \mathrm{~N}$ $\mathrm{NaOH}$ solution was performed (Instituto Adolfo Lutz, 2005). Results were expressed in grams of citric acid per $100 \mathrm{~g}$ of leaf.

(2) Hydrogen ionic potential $(\mathrm{pH}): \mathrm{pH}$ was determined from $1 \mathrm{~g}$ of macerated and diluted leaf $(1 \mathrm{~g}$ of leaf $/ 30 \mathrm{ml}$ of distilled water) using a digital potentiometer with glass membrane (Instituto Adolfo Lutz, 2005).

(3) Vitamin C: determined by titration with Tilman solution (DFI-2,6 dichlorophenol-indophenol 0.02\%) until light pink color, using $1 \mathrm{~g}$ of macerated leaves and transferred to a $100 \mathrm{~mL}$ volumetric flask with oxalic acid $0.5 \%$, according to the methodology proposed by Strohecker and Henning (1967). Results were expressed as mg ascorbic acid per $100 \mathrm{~g}$ of leaf.

(4) Soluble solids (SS): determined by digital refractometer with automatic temperature correction, from the maceration in mortar of $1.0 \mathrm{~g}$ of leaf with $1.0 \mathrm{~mL}$ of distilled water, homogenized, filtered and the results expressed in (\%).

(5) SS/TA ratio: determined by the quotient between soluble solids and titratable acidity.

\subsection{Statistical Analysis}

Treatments were composed of three levels of salinity with $\mathrm{NaCl}$, testing the electrical conductivity of the nutrient solution of 1.65 (control); $3.65 ; 7.65 \mathrm{dS} \mathrm{m}^{-1}$ and two doses of sodium silicate $\left(0.0\right.$ and $\left.2.0 \mathrm{mM} \mathrm{Na}_{2} \mathrm{SiO}_{3}\right)$, with four replicates of two plants each, completely randomized design, in a $3 \times 2$ factorial arrangement. Results were submitted to analysis of variance (Snedecor's F test, $\mathrm{p} \leq 0.05$ ) and comparison of the means by the Scott-Knott test $(\mathrm{p} \leq 0.05)$.

\section{Results}

\subsection{Analysis of Plant Growth}

There was a significant effect ( $\mathrm{p}<0.05$ ) of salinity (sodium chloride- $\mathrm{NaCl}$ ), silicon (sodium silicate- $\mathrm{Na}_{2} \mathrm{SiO}_{3}$ ) and interaction for root length (RL), root and shoot fresh mass and root and shoot dry mass (RFM, SFM, RDM, SDM) and leaf area (LA). For shoot length (SL) and number of leaves (NL), there was no interaction effect of the evaluated factors.

Salinity reduced all variables related to plant growth (Figure 1). For SL, when comparing the highest stress level with the control, this reduction was in the order of $49.1 \%$ in plant growth (Figure 1a). The use of silicon (Si) also resulted in lower shoot growth. For shoot fresh and dry mass, this reduction was of 79.80 and $80 \%$, respectively, in comparison to the control (Figures 1c and 1e). RL, RFM, RD were all reduced with the increase in $\mathrm{NaCl}$ levels, with a more pronounced effect at the highest stress level (Figures $1 \mathrm{~b}, 1 \mathrm{~d}$ and 1f). Based on these results, it was verified that silicate fertilization was not effective in mitigating the deleterious effects of salinity on lettuce growth. 


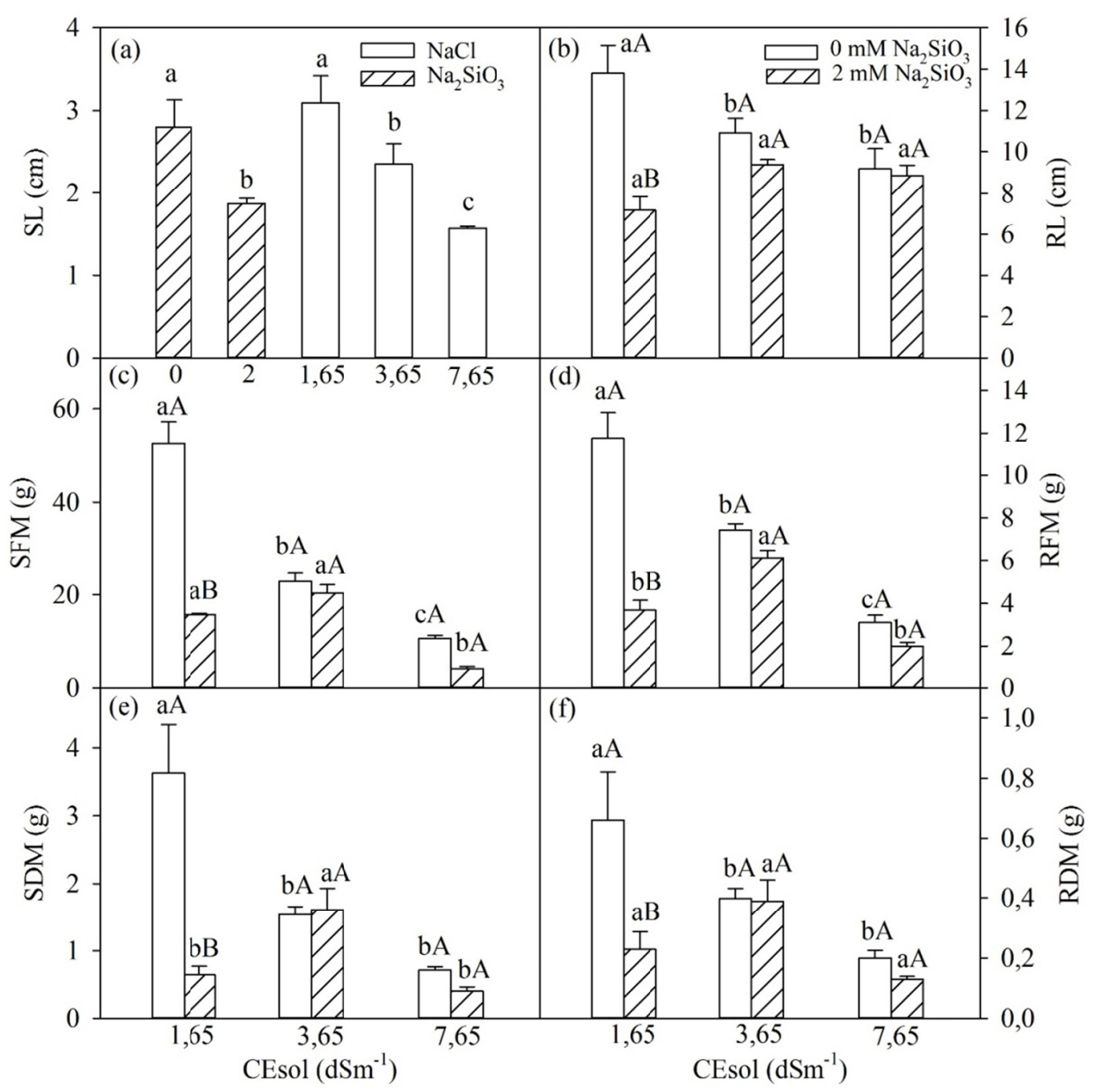

Figure 1. Shoot (SL, a) and root length (RL, b), shoot fresh mass (SFM, c) and root fresh mass (RFM, d), shoot dry mass (SDM, e) and root dry mass (RDM, f) of lettuce plants under salt stress with and without silicon.

Means followed by different lowercase letters among each level of $\mathrm{NaCl}$ and $\mathrm{Na}_{2} \mathrm{SiO}_{3}$ and upper case between $\mathrm{NaCl}$ and $\mathrm{Na}_{2} \mathrm{SiO}_{3}$ levels showed differences among themselves by the Scott-Knott test $(\mathrm{p} \leq 0.05)$. Bars represent the standard error of the mean

The production reduction (PR), considering shoot dry mass in relation to the control treatment was $57 \%$ for moderate stress $\left(3.65 \mathrm{dS} \mathrm{m}^{-1}\right)$ and $80 \%$ for severe stress $\left(7.65 \mathrm{dS} \mathrm{m}^{-1}\right)$. For LA and NL, there was reduction in leaf expansion and leaf emission with salinity increase, being $81.4 \%$ and $27.4 \%$, respectively (Figures $2 \mathrm{a}$ and $2 b)$. 


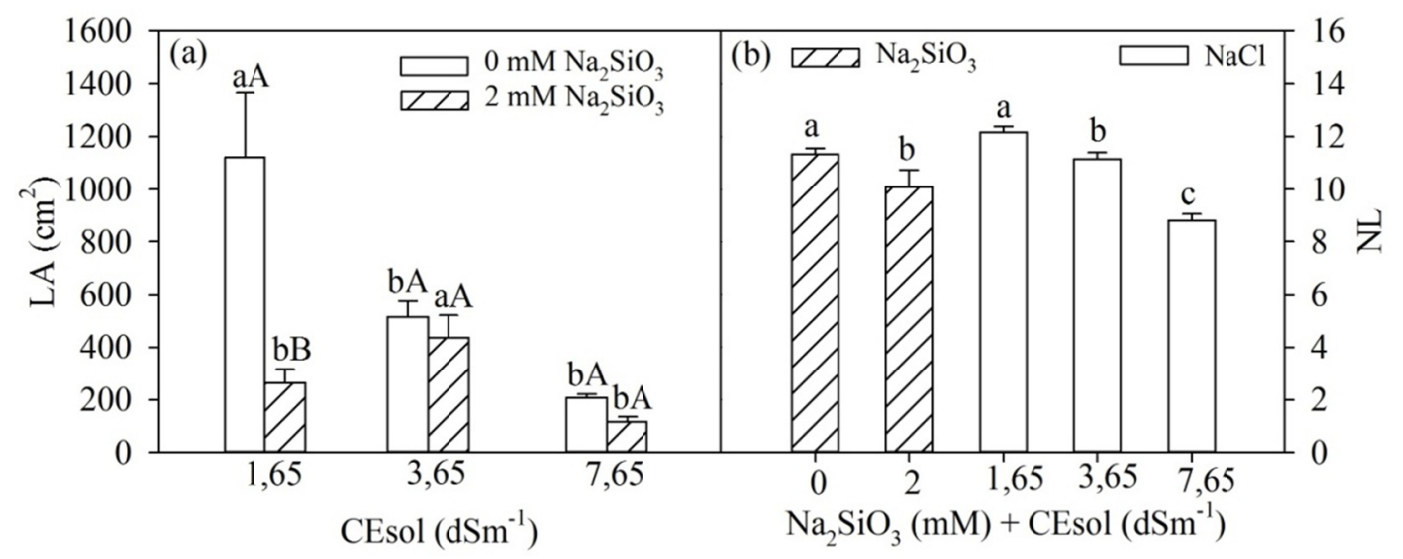

Figure 2. Leaf area (LA, a) and number of leaves (NL, b) of lettuce plants under salt stress with and without silicon. Means followed by different lowercase letters among each level of $\mathrm{NaCl}$ and $\mathrm{Na}_{2} \mathrm{SiO}_{3}$ and upper case between $\mathrm{NaCl}$ and $\mathrm{Na}_{2} \mathrm{SiO}_{3}$ levels showed differences among themselves by the Scott-Knott test $(\mathrm{p} \leq 0.05)$. Bars represent the standard error of the mean

\subsection{Post-harvest Quality Analysis of Leaves}

For variables related to post-harvest quality, there was a significant interaction among the studied factors for vitamin C, soluble solids (SS) and SS/TA ratio. Regarding titratable acidity (TA), there was difference between $\mathrm{NaCl}$ and $\mathrm{Na}_{2} \mathrm{SiO}_{3}$ and for $\mathrm{pH}$, there was no statistical difference. Silicon increased TA by $18.8 \%$ and salinity by $21 \%$ when compared to control (Figure 3a). For vitamin C, this increase was $34 \%$ with the use of silicon in the absence of stress and 39\% for salinity (Figure 3b) and SS was 22\% with silicon (Figure 3d).

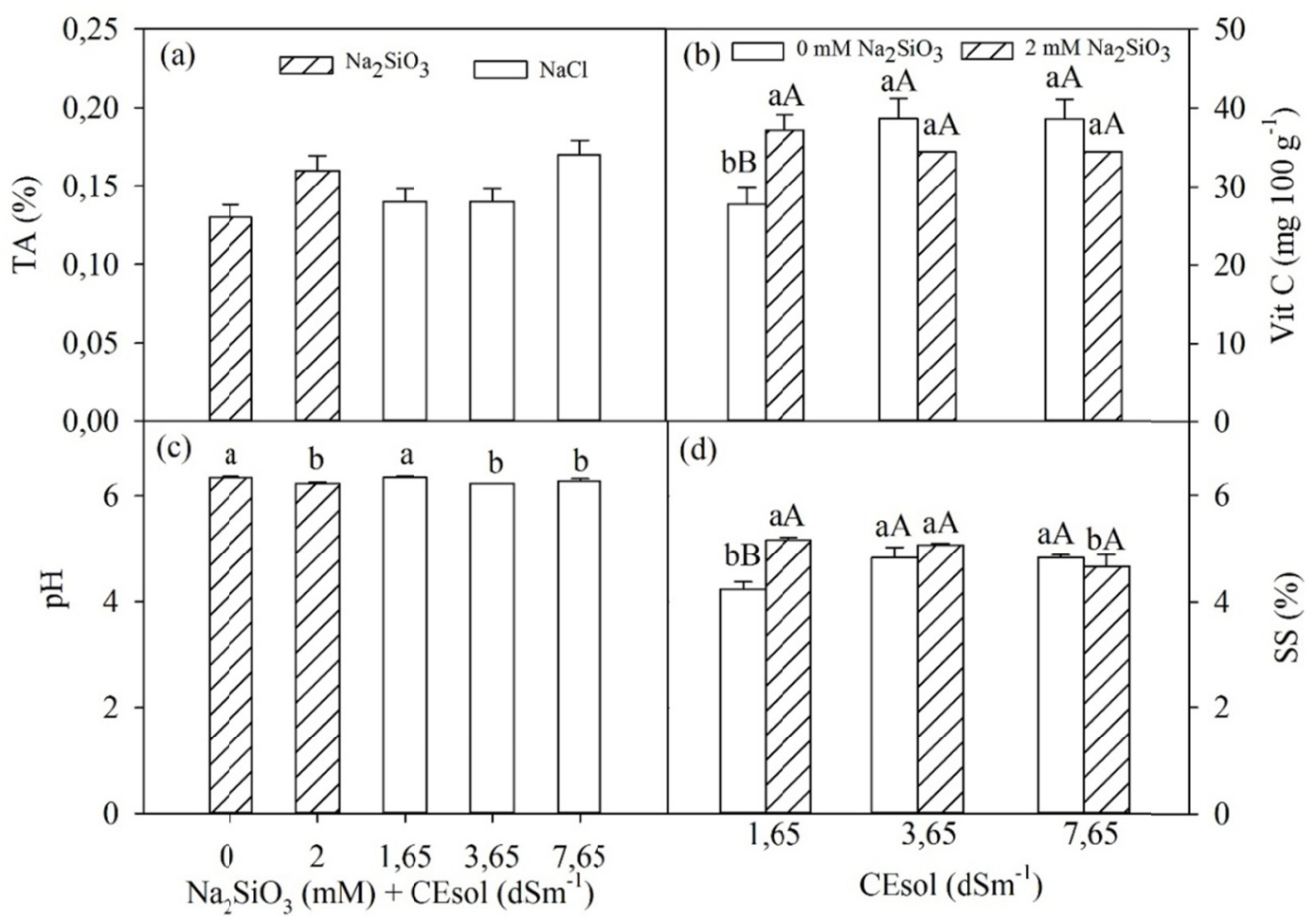

Figure 3. Titratable acidity (TA, a), vitamin $\mathrm{C}(\mathrm{Vit} \mathrm{C}, \mathrm{b})$, hydrogenation potential $(\mathrm{pH}, \mathrm{c}$ ) and soluble solids (SS, d) of lettuce under salt stress with and without silicon. Means followed by different lowercase letters among each

level of $\mathrm{NaCl}$ and $\mathrm{Na}_{2} \mathrm{SiO}_{3}$ and upper case between $\mathrm{NaCl}$ and $\mathrm{Na}_{2} \mathrm{SiO}_{3}$ levels showed differences among themselves by the Scott-Knott test $(\mathrm{p} \leq 0.05)$. Bars represent the standard error of the mean 
SS/AT ratio that expresses a proportion between organic acid content and sugars, that is, a relationship between flavor and aroma, in lettuce leaves, was not affected by salinity. However, in the highest salinity level, silicate fertilization provided a lower mean value for this relation (Figure 4).

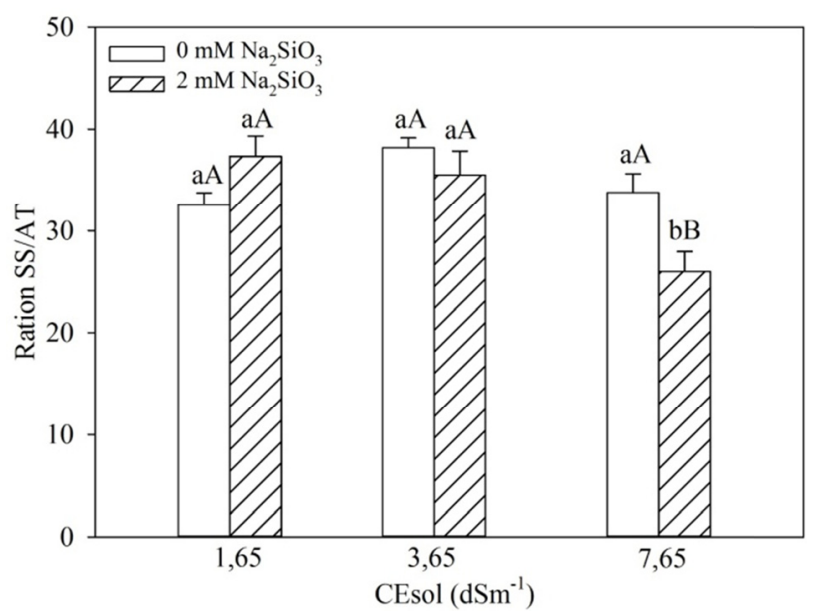

Figure 4. Ration between soluble solids and titratable acidity (SS/AT) of lettuce under salt stress with and without silicon. Means followed by different lowercase letters among each level of $\mathrm{NaCl}$ and $\mathrm{Na}_{2} \mathrm{SiO}_{3}$ and upper case between $\mathrm{NaCl}$ and $\mathrm{Na}_{2} \mathrm{SiO}_{3}$ levels showed differences among themselves by the Scott-Knott test $(\mathrm{p} \leq 0.05)$.

Bars represent the standard error of the mean

\section{Discussion}

\subsection{Analysis of Plant Growth}

Salinity reduced the main components of lettuce growth as shoot fresh and dry mass (Figures 1c and 1e), leaf area (Figure 2a), etc. In salt of stress conditions, the excess dissolved salts in the external solution of root reduces the osmotic potential of the solution as well as the water. Therefore, water potential of the solution becomes smaller than in the root region; thus, the plant has difficulty absorbing water and begins to suffer from the effects of water stress caused by water deficit (Munns \& Tester, 2008; Taiz et al., 2017).

The first response of the plant to saline stress is generally the reduction of growth rate, as it was observed in this study, in which the increase of salinity caused a reduction in all plant growth parameters (Figure 1). In studies with lettuce cultivated with saline wastewater under hydroponic conditions, it was also observed a reduction in parameters such as NL, LA and shoot fresh and dry mass, evidencing that lettuce is sensitive to the increase of salinity (Dias et al., 2011; Paulus et al., 2012).

The effect of the reduction on LA and NL with salinity occurs because the plant absorbs less water. Thus, less water enters the cell, decreasing the potential of turgescence in the plasma membrane. Subsequently, the cell wall extensibility coefficient is reduced and the limiting pressure is increased, resulting in lower leaf expansion and, consequently, lower leaf area (Figure 2a) and lower growth rate (Taiz et al., 2017). Under salt stress, which is usually associated with osmotic stress, plant reduces the expansion and leaf area to decrease the surface of transpiration. With a smaller photosynthetic area, the total photosynthesis of plant tends to decrease and, consequently, causes less accumulation of biomass. Thus, the growth of the plant is lower.

Besides the osmotic effect caused by salt stress, there is also a toxic effect, where high concentrations of ions such as $\mathrm{Na}$ and $\mathrm{Cl}$ in cytosol can cause toxicity to the cells. There is also a nutritional imbalance due to the excess of these ions and, as a result, a deregulation of ionic homeostasis in plants cultivated under salinity conditions is usually observed, resulting in reduced growth and biomass (Liang et al., 2015; Liu et al., 2015; Xie et al., 2015).

By the yield reduction (YR), using SDM, it can be stated that the cultivar was moderately susceptible to the effects of moderate salt stress $\left(3.65 \mathrm{dS} \mathrm{m}^{-1}\right)$ and susceptible to severe stress $\left(7.65 \mathrm{dS} \mathrm{m}^{-1}\right)$. According to Fageria (1985), when a cultivar is under salinity conditions, there is a reduction in yield of 40 to $60 \%$, which is considered moderately susceptible. 


\subsection{Post-harvest Quality Analysis of Leaves}

Salinity increased TA, vitamin C and SS, showing that post-harvest quality of lettuce is influenced by this factor. In other studies, for vitamin $\mathrm{C}$, it was also verified increase of this component as a function of salinity, confirming the significant influence of $\mathrm{NaCl}$ on this variable (Freire et al., 2009). When lettuce was cultivated in nutritive solution and in conventional cultivation in the soil, an increase of vitamin $\mathrm{C}$ was verified in the nutrient solution, showing that it has a higher content in more saline environments (Oshe et al., 2001). Working with lettuce under salt stress, Sarmento et al. (2014) also found an increase in vitamin C and SS content at the highest level of stress.

Salinity produces a secondary stress called oxidative stress, where the production of excess reactive oxygen species (ROS) occurs, and if the plant does not invest in mechanisms of elimination of these ROS, they can cause damage to the cells. Among the defense mechanisms of the plant against these ROS, there are the enzymatic and non-enzymatic antioxidants, where vitamin $\mathrm{C}$ (ascorbic acid) is part of the non-enzymatic and acts both in plants and in animals fighting these ROS. The increase in vitamin $\mathrm{C}$ verified in this research and confirmed in other studies with lettuce under salt stress, may be related to the fact that, under these conditions, there is an increase in ROS production, and there is an increase in the levels of vitamin C in plants' tissues as a defense response to combat oxidative stress. There may also be a dilution effect, that is, the osmotic stress caused by salinity reduces water absorption by the plant with a higher concentration of SS (Beckles, 2012).

Vitamin $\mathrm{C}$ was also increased with the presence of silicon. This element is cited in the literature as a beneficial nutrient for crops due to its effects on improving tolerance to abiotic stresses, such as salinity, increasing the activity of antioxidant enzyme system and combating free radicals produced which are excessively produced in stress situations.

Soluble solids increased in response to stress. This is a parameter that represents all soluble compounds in the plant, with total sugars representing approximately $80 \%$. The increase in SS content can be explained by the fact that salinity reduces the cellular turgor, thus concentrating the amount of salts in the vegetal tissues, and with this, increases the soluble solids under these conditions. The increase in SS content can be explained by the fact that salinity reduces the cell turgor, concentrating the amount of salts in vegetal tissues, increasing soluble solids under these conditions (Beckles, 2012). This effect of SS increase in salinity conditions in irrigation water has already been observed in lettuce cultivars (Freire et al., 2009).

Titratable acidity (TA) was also another parameter that increased as a function of salt and silicon stress. This behavior was also observed by Silva et al. (2013), who verified an increase in TA contents with the use of Si in strawberry. SS/AT ratio, which expresses a ratio between organic acids and sugars, was also increased with increasing $\mathrm{NaCl}$ and $\mathrm{Si}$ in the nutrient solution. The increase in this parameter is an interesting response to the post-harvest quality of the crop, since it is related to flavor, and the higher the proportion of sugars over the acids, the more palatable will be the lettuce leaves.

Si provided benefits in some parameters related to post-harvest of lettuce, such as AT, SS and vitamin C, when compared to the control. However, the mechanisms of how Si acts to increase these variables, such as vitamin C, have not been elucidated yet. Another point to be highlighted is that $\mathrm{Si}$ did not reduce the deleterious effects of salinity on lettuce growth.

\section{Conclusion}

(1) Salinity reduced plant growth, but improved post-harvest quality of the crop.

(2) Silicon was not effective in mitigating the deleterious effects of salinity on lettuce growth, but provided better results for post-harvest quality parameters.

\section{References}

ABCSEM (Associação Brasileira do Comércio da Produção de Sementes e Mudas). (2014). $2^{\circ}$ Levantamento de dados Socioeconomicos da Cadeia Produtiva de Hortaliças no Brasil. Retrieved from http://www. agricultura.gov.br/arq_editor/file/camaras_setoriais/Hortalicas/Dados_Economicos/ABCSEM2011.pdf

Alvares, C. A., Stape, J. L., Sentelhas, P. C., Gonçalves, J. L. M., \& Sparovek, G. (2013). Koöppen's climate classification map for Brazil. Meteorologische Zeitschrift, 22(6), 711-728. https://doi.org/10.1127/ 0941-2948/2013/0507

Beckles, D. M. (2012). Factors affecting the postharvest soluble solids and sugar content of tomato (Solanum lycopersicum L.) fruit. Postharvest Biology and Technology, 63, 129-140. https://doi.org/10.1016/ j.postharvbio.2011.05.016 
Costa, D. M. A., Holanda, J. S., \& Figueiredo Filho, A. O. (2004). Caracterização de solos quanto a afetação por sais na Bacia do Rio Cabugí-Afonso Bezerra-RN. Holos, 20, 01-13. https://doi.org/10.15628/holos.2004.36

Dias, N. S., Sousa Neto, O. N., Cosme, C. R., Jales, A. G. O., Rebouças, J. R. L., \& Oliveira, A. M. (2011). Resposta de cultivares de alface à salinidade da solução nutritiva com rejeito salino em hidroponia. Revista Brasileira de Engenharia Agrícola e Ambiental, 15, 991-995. https://doi.org/10.1590/S1415-436620110 01000001

Fageria, N. K. (1985). Salt tolerance of rice cultivars. Plant and Soil, 88, 237-243. https://doi.org/10.1007/ BF02182450

Fageria, N. K. (1992). Maximizing crop yields (1st ed.). New York: Marcel Dekker.

Furlani, P. R., Bolonhezi, D., Silveira, L. C. P., \& Faquin, V. (1999). Nutrição mineral de hortaliças: Preparo e manejo de soluções nutritivas. Informe Agropecuário, 20, 90-98.

Figueiredo, A. S. T., Resende, J. T. V., Meert, L., Kapp Neto, J., Dias, D. M., Zanin, D. S., \& Schwarz, K. (2010). Produtividade do morangueiro em função de diferentes doses de silício aplicadas via solo e via foliar. Horticultura Brasileira, 28, S870-S876.

Freire, A. G., Oliveira, F. A., Carrilho, M. J. S. O., Oliveira, M. K. T., \& Freitas, D. C. (2009). Qualidade de cultivares de alface produzida em condições salinas. Revista Caatinga, 22, 81-88.

Galati, V. C., Guimarães, J. E. R., Marques, K. M., Fernandes, J. D. R., Cecílio Filho, A. B., \& Mattiuz, B. (2015). Aplicação de silício, em hidroponia, na conservação pós-colheita de alface americana 'Lucy Brown' minimamente processada. Ciência Rural, 45, 1932-1938. https://doi.org/10.1590/0103-8478cr20140334

Instituto Adolfo Lutz. (2005). Métodos Físico-Químicos para Análise de Alimentos (4th ed.). São Paulo: IAL.

Kraska, J. E., \& Breitenbeck, G. A. (2010). Survey of the silicon status of flooded rice in Louisiana. Agronomy Journal, 102, 523-529. https://doi.org/10.2134/agronj2009.0146

Liang, X., Wang, H., Hu, Y., Mao, L., Sun, L., Dong, T., .. Bi, Y. (2015). Silicon does not mitigate cell death in cultured tobacco BY-2 cells subjected to salinity without ethylene emission. Plant Cell Reports, 34, 331-343. https://doi.org/10.1007/s00299-014-1712-6

Liu, P., Yin, L., Wang, S., Zhang, M., Deng, X., Zhang, S., \& Tanaka, K. (2015). Enhanced root hydraulic conductance by aquaporin regulation accounts for silicon alleviated salt-induced osmotic stress in Sorghum bicolor L. Environmental and Experimental. Botany, 111, 42-51. https://doi.org/10.1016/j.envexpbot. 2014.10.006

Lima, M. A., Castro, V. F., Vidal, J. B., \& Enéas-Filho, J. (2011). Aplicação de silício em milho e feijão-de-corda sob estresse salino. Revista Ciência Agronômica, 42, 398-403. https://doi.org/10.1590/S1806-66902011 000200019

Maas, E. V. (1986). Salt tolerance of plants. Applied Agricultural Research, 01, 12-25.

Marodin, J. C., Resende, J. T. V., Morales, R.G. F., Faria, M. V., Trevisam, A. R., Figueiredo, A. S. T., \& Dias, D. M. (2016). Tomato post-harvest durability and physicochemical quality depending on silicon sources and doses. Horticultura Brasileira, 34, 361-366. https://doi.org/10.1590/S0102-05362016003009

Martinez-Beltran, J., \& Manzur, C. L. (2005). Overview of salinity problems in the world and FAO strategies to address the problem. Proceedings of the International Salinity Forum (pp. 311-314).

Miranda, J. R. P., Carvalho, J. G., Freire, A. L. O., \& Fernandes, A. R. (2010). Avaliação do silício como atenuador dos efeitos da salinidade na nutrição mineral de clones de Anacardium occidentale L. Engenharia Ambiental, 07, 144-156.

Munns, R., \& Tester, M. (2008). Mechanisms of salinity tolerance. Annual Review of Plant Biology, 59, 651-81. https://doi.org/10.1146/annurev.arplant.59.032607.092911

Oshe, S., Nogueira Filho, S., Manfron, P. A., \& Dourado-Neto, D. (2001). Composição centesimal e teores de vitamina $\mathrm{C}$, cálcio e fósforo de seis cultivares de alface produzidas sob dois sistemas de cultivo. Revista Insula, 30, 47-62.

Paulus, D., Paulus, E., Nava, G. A., \& Moura, C. A. (2012). Crescimento, consumo hídrico e composição mineral de alface cultivada em hidroponia com águas salinas. Revista Ceres, 59, 110-117. https://doi.org/ 10.1590/S0034-737X2012000100016 
Resende, G. M., Yuri, J. E., \& Souza, R. J. (2007). Épocas de plantio e doses de silício no rendimento de alface tipo americana. Horticultura Brasileira, 25, 455-459. https://doi.org/10.1590/S0102-05362007000300026

Sarmento, J. D. A., Morais, P. L. D., Almeida, M. L. B., Sousa Neto, O. N., \& Dias, N. S. (2014). Qualidade e conservação da alface cultivada com rejeito da dessalinização. Revista Caatinga, 27, 90-97.

Silva, M. L. S., Resende, J. T. V., Trevizam, A., Figueiredo, A. S. T., \& Schwarz, K. (2013). Influência do silício na produção e na qualidade de frutos do morangueiro. Semina: Ciências Agrárias, 34, 3411-3424. https://doi.org/10.5433/1679-0359.2013v34n6Sup11p3411

Strohecker, R. L., \& Henning, H. M. (1967). Análises de vitaminas: Métodos comprobados. Madri: Paz Montalvo.

Shahbaz, M., \& Ashraf, M. (2013). Improving salinity tolerance in cereals. Critical Reviews in Plant Sciences, 32, 237-249. https://doi.org/10.1080/07352689.2013.758544

Shrivastava, P., \& Kumar, R. (2015). Soil salinity: A serious environmental issue and plant growth promoting bacteria as one of the tools for its alleviation. Saudi Journal of Biological Sciences, 22, 123-131. http://doi.org/10.1016/j.sjbs.2014.12.001

Taiz, L., Zeiger, E., Møller, I. M., \& Murphy, A. (2017). Fisiologia e Desenvolvimento Vegetal. 6. ed. Porto Alegre: Artmed.

Tuna, A. L., Kaya, C., Higgs, D., Amador, B. M., Aydemir, S., \& Girgin, A. R. (2008). Silicon improves salinity tolerance in wheat plants. Environmental and Experimental Botany, 62, 10-16. https://doi.org/10.1016/ j.envexpbot.2007.06.006

Xie, Z., Song, R., Shao, H., Song, F., Xu, H., \& Lu, Y. (2015). Silicon improves maize photosynthesis in saline-alkaline soils. The Scientific World Journal, 2015, Article ID 245072. https://doi.org/10.1155/ $2015 / 245072$

\section{Copyrights}

Copyright for this article is retained by the author(s), with first publication rights granted to the journal.

This is an open-access article distributed under the terms and conditions of the Creative Commons Attribution license (http://creativecommons.org/licenses/by/4.0/). 